\title{
UPAYA MENINGKATKAN SELF CONFIDENCE SISWA SMK MENGGUNAKAN PENDEKATAN OPEN ENDED
}

\author{
Fitriani Nur Salamah ${ }^{1}$, Risma Amelia $^{2}$ \\ 1,2 Pendidikan Matematika, IKIP SILIWANGI \\ Jl. Terusan Jendral Sudirman Cimahi 40526 \\ fnursalamah@gmail.com
}

The importance of the contribution of mathematics in human activity, especially in the successors of superior generations demands more learning that fosters students' intelligence and skill during the learning process. The ability of self-confidence is very needed for students to be able to achieve skills for superior generations. Through using an open-ended approach, students are expected to grow diverse ideas and mathematical ways of thinking so students are accustomed to completing various solutions or strategies. This study is a Classroom Action Research (CAR). The subjects in this study were students of class X RPL B in one of the CIMahi City SMKS. Based on the results of data analysis in cycle II student activity increased from each indicator 1) Belief in self-ability ability $61.81 \%$ 2) Acting independently in making decisions $67.92 \%$ 3) Having positive self concepts $69.89 \%$ and 4) Courageous expressing opinions $70.38 \%$ with the results achieved can be expressed that the ability of self-confidence increases in learning using the open-ended approach.

Keywords: Self-Confidence, Open Ended Approach

\begin{abstract}
Abstrak
Pentingnya andil matematika dalam kesibukan manusia terutama dalam penerus generasi-generasi yang unggul menuntut semakin diperlukannya pembelajaran yang menumbuhkan kecerdasan dan kecapakapan siswa saat proses pembelajaran. Kemampuan self-confidence sangat dipelukan untuk siswa agar dapat tercapai kecakapan bagi generasi unggul. Melalui pendekatan open ended, siswa diharapkan dapat menumbuhkan ide-ide yang beragam dan cara berpikir matematis sehingga siswa terbiasa dalam menyelesaikan berbagai penyelesaian atau strategi. Penelitian ini merupakan Penelitian Tindakan Kelas (PTK). Subyek dalam penelitian ini adalah siswa kelas X RPL B di salah satu SMKS Kota Cimahi. Berdasarkan hasil analisis data pada siklus II aktivitas siswa meningkat dari setiap indikator 1) Percaya pada kemampuan diri sediri 61,81\% 2) Bertindak mandiri dalam mengambil keputusan 67,92\% 3) Memiliki konsep diri yang positif 69,89\% dan 4) Berani mengungkapkan pendapat $70,38 \%$ dengan hasil yang dicapai tersebut dapat dinyatakan kemampuan self-confidence meningkat dalam pembelajaran menggunakan pendekatan open ended.
\end{abstract}

Kata Kunci: Self-Confidence, Pendekatan Open Ended.

Matematika memiliki kontribusi penting bagi manusia, salah satunya sebagai pembentuk konsep pemikiran manusia yang berbudi pekerti baik, berpendidikan, cekatan. Ini juga penting dalam kehidupan yang pada jaman ini sebagai sudah lebih modern, karena dapat membuat lebih siap secara mental, terbuka dan mudah menyesuaikan dengan berbagai situasi dan permasalahan yang dihadapi. Sehingga matematika dianggap dapat membuat generasi-generasi unggul untuk siap bergandengan dengan perubahan pada setiap jaman yang sangat bermanfaat bagi kehidupan sehari-hari. Hal ini dikarena berbagai masalah kehidupan sehari-hari dapat dituangkan dalam matematika kemudian dicari solusinya berdasarkan pedoman yang terdapat dalam matematika. Menurut Hapsari (2011) Matematika adalah ilmu mengenai kerangka berpikir yang absurd di sekitar kita, sehingga semua yang kita pelajari dapat diterapkan ke dalam matematika. Matematika merupakan sebuah jembatan 
untuk membuat strategi dalam permasalahan, juga sebagai penunjang dalam ilmu pengetahuan dan teknologi, dan memberikan jalan untuk menggambarkan situasi yang benar-benar terjadi.

Untuk dapat menjadi generasi yang unggul, Pendidikan harus dapat membimbing kearah tersebut, menumbuhkan kecerdasan ataupun kepiawaian dalam menerima pembelajaran tersebut. Usaha membentuk suatu kecakapan dalam diri siswa SMK guna mencapai tujuan pendidikan. Siswa SMK dinilai sudah terasah kemampuan yang mereka pilih disekolahnya. Tentu saja generasi unggul dapat tumbuh dalam sekolah menengah kejuruan ini. Karena, guru menanggung andil yang berarti dalam proses pembelajaran. Salah satu aspek yang harus diperhatikan oleh guru adalah kemampuan self-confidence siswa. Dalam dunia pendidikan self-confidence merupakan aspek penggerak terjadinya interaksi yang baik di dalam kelas.

Menurut Molloy (2010) self-confidence adalah dimana seseorang yakin dirinya bisa, percaya dan puas, lalu akhirnya seseorang tersebut berani mengambil tindakan sendiri tanpa perlu persetujuan orang lain. Sedangkan self-confidence Nur Ghufron dan Rini R.S (2011) berpandangan keyakinan diri dalam melakukan tindakan pada diri sebagai pembangun pribadi yang positif yang harus tertanam pada keyakinan kemampuan diri, tidak mudah menyerah, rasional, bertanggung jawab, ilmiah dan sesuai dengan keadaan. Menurut Akbar, G. A, dkk. (2018) bahwa sudut pandang pada siswa terhadap matematika yang dinilai sangat berguna dalam kehidupan dan dapat menumbuhkan rasa percaya diri, rajin serta tekun masih kurang sehingga kemampuan Self confidence siswa dalam matematika adalah suatu yang harus ditingkatkan.

Untuk membentuk self-confidence dalam pembelajaran matematika yaitu dengan adanya interaksi antara siswa dan guru juga siswa dengan siswa. Peran penting dalam pembelajaran juga terdapat pada guru yang dalam penyampaiannya menggunakan metode pembelajaran yang diterapkannya di kelas secara tidak langsung berdampak kepada siswa dan terhadap self-confidence siswa, disaat siswa menghadapi keadaan yang menantang tetapi memiliki perasaan senang maka selfconfidence siswa pun akan meningkat. Menurut Hapsari (2011) self-confidence adalah suatu rasa yakin yang akan membentuk pemahaman dan perasaan siswa mengenai kemampuannya dalam segala aspek. Lautser (Hendriana, Rohaeti, Sumarmo, 2017) mengatakan indikator dari self-confidence ada 4 yaitu, 1) Percaya pada kemampuan diri sediri, 2) Bertindak sendiri untuk membuat keputusan, 3) Memiliki perasaan yang positif dan 4) Berani mengungkapkan pendapat.

Dari indikator-indikator kemampuan self-confidence perlu adanya pembelajaran yang menumbuhkan aspek-aspek tersebut. Sebab itu peneliti menggunakan pembelajaran yang menggunakan pendekatan open ended. Menurut Sulianto (2011) pembelajaran dengan menggunakan open ended dimulai dari memberi masalah terbuka dan masalah tersebut dapat membawa siswa untuk menyelesaikannya dengan berbagai macam penyelesaian, sehingga dapat memicu kemampuan kecerdasan berdasarkan pengalaman siswa dalam proses pembelajaran. Sejalan dengan Fadhilaturrahmi (2017) bahwa dengan pembelajaran open ended merupakan salah satu usaha dengan hal yang baru dalam pendidikan matematika agar siswa dapat menggali ide yang bermacam-macam di 
dalam kegiatan permasalahan sehingga siswa memikirkan cara/strategi mencari solusi permasalahan. Pendekatan open-ended bertujuan agar siswa mengelaborasi ide-ide kreatif dan pola pikir matematis. Dengan diberikan masalah yang bersifat terbuka, siswa terbiasa untuk melakukan penyelidikan caracara dalam menyelesaikan masalah. Selain itu siswa juga akan lebih mendalami konsep sehingga dalam pengerjaan proses penyelesaian suatu masalah siswa sadar akan pentingnya proses dana hasil yang diperoleh. Sehingga siswa diberi kesempatan kepada siswa untuk berpikir bebas sesuai untuk menyelesaikan permasalahan.

\section{METODE}

Subjek penelitian adalah siswa kelas X RPL B di salah satu SMKS Kota Cimahi yang berjumlah 30 siswa dengan pokok bahasan sudut berelasi dan koordinat kutub. Jenis penelitian menggunakan penelitian tindakan kelas (PTK) dengan metode kualitatif. Menurut Arikunto (2006), PTK merupakan upaya untuk meningkatkan proses/hasil pembelajaran yang ingin dicapai oleh seorang guru. Menurut Sumardi (2010), penelitian tindakan kelas adalah pengkajian yang dilakukan oleh guru dengan menyiapkan secara terurut dengan rencana-rencana yang disiapkan dengan tujuan memperbaiki pembelajaran. Pendekatan kualitatif dalam penelitian ini digunakan saat mengamati kegiatan-kegiatan siswa selam proses pembelajaran matematika.

Pembelajaran ini menggunakan pendekatan open ended, dilaksanakan dua siklus pembelajaran. Tindakan pendahuluan mengadakan tes pendahuluan berupa angket untuk mengetahui kemampuan self-confidence siswa. Setelah dilaksanakannya pembelajaran, siswa diberi tes akhir I dan menganalisis untuk mengetahui kenaikan dari setiap indikator kemampuan self-confidence siswa dan digunakan sebagai acuan perbaikan untuk melaksanakan siklus II. Setelah selesai, data angket dibandingkan dengan yang sebelumnya.

\section{HASIL DAN PEMBAHASAN}

Berdasarkan hasil penelitian tindakan kelas pada X RPL B salah satu SMKS Kota Cimahi ini pada siklus I dan siklus II kemampuan self-confidence siswa mengalami peningkatan dalam indikatorindikator yang ttercantum dalam aktifitas proses pembelajaran. Aktivitas siswa yang ditinjau ini yaitu meliputi, aktivitas indikator dalam kemampuan sel-confidence dalam proses pembelajaran yang dilakukan kerjasama kelompok maupun individu. Hasil pemantauam aktivitas siswa dapat dilihat pada tabel berikut:

Tabel 1.

Presentase Aktivitas Siswa

\begin{tabular}{|c|l|c|c|}
\hline No & \multicolumn{1}{|c|}{ Indikator } & Siklus I & Siklus II \\
\hline 1. & Percaya pada kemampuan diri sediri & $55,78 \%$ & $61,81 \%$ \\
\hline 2. & Bertindak sendiri untuk membuat keputusan. & $60,38 \%$ & $67,92 \%$ \\
\hline
\end{tabular}




\begin{tabular}{|l|l|l|l|}
\hline 3. & Memiliki perasaan yang positif & $61,67 \%$ & $69,89 \%$ \\
\hline 4. & Berani mengungkapkan pendapat & $64,17 \%$ & $70,38 \%$ \\
\hline
\end{tabular}

Penerapan pembelajaran dengan menggunakan pendekatan open ended untuk meningkatkan kemampuan self-confidence siswa pokok bahasan sudut berelasi dan koordinat kutub. Kegiatan ini berjalan dengan baik, siswa merasakan terdorong dan lebih penasaran/tertarik dalam proses pembelajaran sehingga aktifitas siswa cukup kondusif di dalam kelas. Peneliti dibantu oleh observer yaitu teman sejawat dalam melaksanakan pembelajaran. Dalam pembelajaran siswa belajar dalam kelompok. Guru membagi siswa menjadi 6 kelompok, masing-masing kelompok berjumlah 5 siswa. Siswa mulai berkelompok, salah satu perwakilan kelompok mengambil LKS. LKS ini diberikan untuk mempermudah siswa mencapai tujuan pembelajaran dengan menerapkan pendekatan open ended.

Pada pembelajaran yang pertama masih ada beberapa kendala dan belum memenuhi kriteria yang diharapkan. Sehingga peneliti melanjutkan pada siklus berikutnya. Siklus I dilselenggara dengan baik, proses pembelajaran dilakukan sama dengan yang pertama. Di siklus II aktifitas siswa mulai mengalami perubahan pada setiap indikator yang ingin dicapai. Hal tersebut terbukti dengan meningkatnya hasil dari angket kemampuan self-confidence siswa pada kedua siklus, sehingga tidak perlu melaksanakan siklus berikutnya. Dalam pendekatan open-ended siswa didorong untuk belajar sendiri secara mandiri. Siswa belajar giat dengan masuk kedalam konsep-dan prinsip dalam memecahkan masalah, dan guru merangsang siswa agar permasalahan open ended ini dapat dijadikan sebuah pengalaman yang beraneka sehingga lebih mengingatnya dalam pembelajaran.

Aktivitas siswa yaitu meliputi indikator dalam kemampuan self-confidence saat proses pembelajaran baik kerjasama dalam kelompok ataupun individu. Hasil observasinya pada kedua siklus, yaitu indikator pertama 55,78\% menjadi $61,81 \%$, indikator kedua $60,38 \%$ meningkat menjadi $67,92 \%$, ketiga $61,67 \%$ menjadi $69,89 \%$ dan terakhir $64,17 \%$ jadi $70,38 \%$.

Penelitian ini adalah penelitian tindakan kelas yang bertujuan untuk mengetahui bagaimana aktivitas siswa selagi penerapan pendekatan open ended. Dari data yang didapat, maka akan dibahas penerapan pembelajaran, aktivitas siswa selama proses pembelajaran dan hasil observasi siswa selama penerapan pendekatan open ended. Penerapan pendekatan open ended berjalan dengan baik.

Dalam penerapan pendekatan open ended pada siklus I berdasarkan pengamatan kesibukan siswa pada saat proses pembelajaran dapat dikatakan lancar meskipun pada siklus I masih terdapat siswa yang belum sesuai dengan indikator dihapkan oleh peneliti diantaranya adalah sebagai berikut: 1) Siswa masih tidak yakin dengan kemampuan yang dimiliki diri sendiri, 2) Kurangnya kesadaran dalam bertindak mandiri, seperti menulis atau mengerjakan soal, 3) Beberapa siswa tidak yakin dengan solusi permalasahan yang telah dijawab olehnya, 4) Guru mempersilakan siswa untuk mempresentasikan hasil diskusinya namun masik banyak yang malu dan takut hal ini mungkin dikarenakan kebiasaan mereka pada kegiatan sebelumnya yang pasif dalam pembelajaran. 
Menurut Mufarizuddin (2018) proses aktivitas siswa dalam pembelajaran sangat berpengaruh pada kemapuan yang ingin dicapai oleh siswa, oleh karena itu siswa mesti mendorong diri agar berusaha menemukan penyelesaian tersebut. Hal ini sejalan dengan Jatisunda (Yuliani, Setiawan, Hendriana, 2019) bahwa jika siswa dapat lebih memahami suatu konsep matematika yang dipelajari maka kendala-kendala yang dihadapi oleh siswa haruslah disingkirkan.

Menurut Amelia (2015) untuk mengevaluasi suatu kemampuan yang ingin dicapai oleh siswa seperti kepercayaan diri dan arah berfikir, siswa haruslah dibimbing hingga dalam menganalisis permasalahan mereka dapat menyelesaikannya dengan sendiri dan diberi dorongan agar lebih meluapkan isi pikiran untuk masalah matematika tersebut. Maka berdasarkan penyataan diatas kendala-kendala pada siklus I diperbaiki dan mendapatkan hasil peningkatan pada siswa yaitu: 1) Siswa mulai yakin dengan kemampuan yang dimiliki diri sendiri, 2) Berinisiatif dalam belajar karena diberi sokongan oleh peneliti agar bisa lebih baik lagi, (3) Siswa mulai yakin dengan solusi permalasahan yang telah dijawab olehnya dan (4) Tidak malu atau takut dalam mempresentasikan hasil karena guru memberikan motivasi pada siswa. Pada intinya di siklus II ini guru merencakan strategi berkomunikasi lebih dekat sehingga memungkinkan siswa untuk terampil dalam berbicara atau mengungkapkan dan merefleksikan pikiran siswa.

\section{KESIMPULAN}

Dari yang telah diuraikan pada hasil dan pembahasan, sehingga peneliti simpulkan sebagai berikut: 1) Upaya meningkatkan kemampuan self-confidence dengan open ended, siswa kelas pada $\mathrm{X}$ RPL B di salah satu SMKS Kota Cimahi dengan pokok bahasan sudut berelasi dan koordinat kutub berjalan dengan baik, siswa terlihat lebih antusias dan tertarik dalam mengikuti pelajaran. Dalam kegiatan pembelajaran ini telah di rencanakan dan disusun sebagaimana tahap-tahap dalam pendekatan open ended. Meskipun dalam pelaksanaannya masih terdapat sedikit hambatan, hal itu dapat diatasi dengan memberikan bimbingan dan dorongan motivasi yang lebih sering diberikan terhadap siswa. 2) Suasana dalam kelas menjadi aktif terutama indicator dalam kemampuan selfconfidence pada saat menggunakan pendekatan open ended dibanding pembelajaran biasa.

\section{DAFTAR PUSTAKA}

Amelia, R. (2016). Pencapaian kemampuan penalaran matematis siswa SMP dengan menggunakan metode pembelajaran inkuiri terbimbing. P2M STKIP Siliwangi, 2(1), 98-105.

Arikunto, S. (2006). Prosedur Penelitian Suatu Pendekatan Praktek. Jakarta : Rineka Cipta

Diniyah, A. N., Akbar, G. A. M., Akbar, P., Nurjaman, A., \& Bernard, M. (2018). Analisis Kemampuan Kemampuan Penalaran dan Self Confidence Siswa SMA dalam Materi Peluang. Journal on Education, 1(1), 14-21

Fadhilaturrahmi, F. (2017). Pengaruh pendekatan open ended dan Pendekatan Scientific terhadap Kemampuan Koneksi Matematis Siswa Sekolah Dasar. Mimbar Sekolah Dasar, 4 (2), 117-127. 
Hapsari, M. J. (2011). Upaya Meningkatkan Self-Confidence Siswa Dalam Pembelajaran Matematika Melalui Model Inkuiri Terbimbing. Jurnal Prosiding ISBN, 978-979.

Nur Ghufron \& Rini R.S. (2011). Teori-Teori Psikologi. Jogjakarta: Ar-Ruzz Media.

Molloy, A. (2010). Coach Your Self Mimpi Tercapai, Target Terpenuhi. (Terjemahan Retnadi Nur'aini dari ASPIRATIONS: 8 Easy Steps to Coach Yourself to Succes). Jakarta: Raih Asa Sukses.

Mufarizuddin, M. (2018). Analisis Kesulitan Pembelajaran Matematika Siswa Kelas V SD Negeri 012 Bangkinang Kota. Journal on Education, 1(1), 40-47.

Rizal, M. S. (2018). Pengaruh Model Pembelajaran Kooperatif Tipe Think Talk Write (TTW) Terhadap Keaktifan Belajar Siswa dalam Pembelajaran Matematika kelas IV SDM 020 Kuok. Jurnal Pendidikan Matematika, 2(1), 105-117.

Sulianto, J. (2011). Keefektifan Model Pembelajaran Kontekstual dengan pendekatan open ended dalam aspek penalaran dan pemecahan masalah pada materi segitiga di kelas VII. Malih Peddas (Majalah Ilmiah Pendidikan Dasar), 1(1).

Sunardi. (2010). Penelitian Tindakan Kelas dalam Modul Bidang Studi Guru Kelas SD. Jember : Universitas Jember.

Yuliani, S. R., Setiawan, W., \& Hendriana, H. (2018). ANALISIS KESALAHAN SISWA SMP PADA MATERI PERBANDINGAN DITINJAU DARI INDIKATOR KEMAMPUAN PEMECAHAN MASALAH MATEMATIS. Journal on Education, 1(2), 77-82. 